\title{
Antagonistic Landscapes
}

\section{Sen, Somdeep}

Published in:

Environment and Planning C: Politics and Space

DOI:

10.1177/2399654420948529

Publication date:

2021

Document Version

Peer reviewed version

Citation for published version (APA):

Sen, S. (2021). Antagonistic Landscapes. Environment and Planning C: Politics and Space, 39(4), 705-721. https://doi.org/10.1177/2399654420948529

\section{General rights}

Copyright and moral rights for the publications made accessible in the public portal are retained by the authors and/or other copyright owners and it is a condition of accessing publications that users recognise and abide by the legal requirements associated with these rights.

- Users may download and print one copy of any publication from the public portal for the purpose of private study or research.

- You may not further distribute the material or use it for any profit-making activity or commercial gain.

- You may freely distribute the URL identifying the publication in the public portal.

Take down policy

If you believe that this document breaches copyright please contact rucforsk@kb.dk providing details, and we will remove access to the work immediately and investigate your claim. 


\title{
ANTAGONISTIC LANDSCAPES
}

\section{Somdeep Sen, Roskilde University}

\begin{abstract}
This article introduces and develops the concept of "antagonistic landscapes" on the basis of fieldwork conducted in the Israeli settlement Efrat in the occupied West Bank and the Hebrew University of Jerusalem campus on Mount Scopus. The concept refers to the ways in which powerful actors antagonize "unwanted" communities by means of the physicality of the landscape. Both fieldwork sites, built on hills, use higher ground to tower over, yet overlook, the presence of "unwanted" Palestinian communities in the valleys below, thereby constituting prototypically antagonistic landscapes. That said, as expressions of utopian dreams, antagonistic landscapes require the erasure of what already exists. But Palestinians continue to lay claim to the landscape. As a consequence, then, these dreams remain utopian since by simply persisting and refusing to be entirely effaced the antagonized inscribe themselves into the fabric of the landscape. Antagonistic landscapes thus display both the dreams that the antagonizers hoped to realize, and the narratives of those whom they failed to replace.
\end{abstract}

Keywords: land, antagonism, elimination, altitude, Israel-Palestine

On a Friday before Shabbat in mid-November 2015 I visited Efrat, an Israeli settlement in the occupied West Bank. Because I'm dark-skinned, Israeli settlers and soldiers often assume that I'm Palestinian. So, my presence that day in the settlement had raised some suspicion among those out shopping for the weekend. Most just stared, but when I began taking pictures one of them decided to inquire about my "business" in Efrat. In a friendly tone, she asked, “Are you a tourist?". I replied, "Yes. I'm visiting a friend for the weekend." She smiled, "Great. Welcome. Enjoy your stay." At that point I was taking pictures of Neve Daniel and Elazar, two other settlements visible from the western edge of Efrat. Curious, the settler asked, "What are you taking pictures of?”. I responded, “Just the view. It's so beautiful here. So peaceful."

While I was taken by the beauty of the landscape, I was also well aware of the irony of using the word "peaceful." At the time, the "knife intifada" was well underway and the occupied West Bank and Jerusalem had witnessed several stabbing attacks and extra-judicial killings of Palestinians (Taustad, 2017; Alsaafin, 2017). But I was hoping to provoke a response from the settler. I had spent the two hours prior to this encounter trying to catch a glimpse of the neighbouring Palestinian village Wadi 
an Nis, located east of Efrat. With the settlement situated on a hill and the Palestinian village in the adjacent valley, Wadi an Nis should have been in plain sight (like Neve Daniel and Elazar in the west). However, it was entirely invisible. It seemed as if all the physical structures in the east of Efrat were built purposefully to block one's view of the Palestinians in the area. Expectedly, the settler scoffed when I called Efrat "peaceful." She said, "This place is not peaceful. We have Arabs here. But you can't see them from here. We like to maintain peaceful views."

This effort to create a façade of peace by maintaining a particular view from the settlement, reminds us that landscapes are often the product of dreams. In Efrat, a settlement considered illegal under international law, the dream was that of a peaceful place unencumbered by the Palestinians living in its vicinity who challenge the legality of its existence in the occupied West Bank. Therefore, the entire settlement is built facing other Israeli settlements, and away from the Palestinian village, as a way of feigning a landscape devoid of Palestinian presence. As is the case with Israel's settler colonial schemes in general that work to materially erase the signature of Palestinian existence (Sen, 2020: 20-34; Collins, 2012: 19-48; Salamanca, et. al. 2012), the premise of this dream is also violent as it too simulates the non-existence of a people. A claim to the landscape visible from Efrat is foundational to the Palestinian struggle for a national territorial home (Bardenstein, 1998; Falah, 1999; Griffiths, 2017). But, this "peaceful view" erases Palestinians and renders their national aspirations invisible to those looking out from the settlement. Such a simulation of Palestinian nonexistence then gains some materiality in the perception of those living in Efrat. This was evident when I asked the settler in Efrat about the location of Wadi an Nis. She replied, “I don't know where it is. You can't see it from here. I'm not sure if you can even call it a village. It is just a random bunch of people, Arabs or Palestinians or whatever you want to call them. Nothing to see there."1

This way of writing a dream into a landscape results in what I call an antagonistic landscape. In this article I introduce and develop this concept on the basis of my ethnographic fieldwork in Efrat and the Hebrew University of Jerusalem (HUJI) campus on Mount Scopus in 2015 and 2016. To this end, I alternate between ethnographic observations and interviews that elaborate the antagonizing narrative that animate the physicality of these sites as well as those that display the perspectives of the antagonized - namely, Palestinians who are compelled to live while "looking up" towards Efrat and HUJI. In view of this ethnographic data, I then propose that, fundamentally, a landscape is antagonistic when the dream it communicates aims to antagonize. Efrat is antagonistic to the presence of Palestinian as it simulates the dream of their non-existence through (de-Palestinized) "peaceful 
views." Similarly, I go on to argue, the design and planning of the HUJI on Mount Scopus is also meant to de-Palestinize the landscape. This is achieved, for one thing, through the Israeli-ness of its spatial identity, supported not least by the national(ist) iconography present across the premises of the campus. Further, like Wadi an Nis, Issawiya - a Palestinian village located in the adjacent valley - is also relegated to the periphery of the views from the HUJI campus on Mount Scopus. This said, the notion of antagonistic landscapes is distinct from contested landscapes. The latter insinuates overlapping claims to a land. But the former involves a politicization of the physical features of a place; namely, its verticality. So, be it the manner in which HUJI sits on a hill (i.e. Mount Scopus) or the way Efrat is located on higher ground vis-à-vis the neighbouring Palestinian village - these antagonistic landscapes (physically) tower over Palestinian communities and allow those looking out to look over or "overlook" (Olwig, 2018) Palestinians living in the valley. This ability to overlook then helps give materiality to the dream of a landscape sans Palestinian presence.

Antagonistic landscapes however are not defined solely by what they dream to achieve. They are equally characterized by what they fail to accomplish. Such landscapes are driven by utopian dreams. These dreams therefore require the elimination of what already exists. However, I demonstrate that since these are utopian visions, the making of the new landscape has to contend with the persistent presence of, and the inability to entirely efface, what already exists. So, as Wadi an Nis and Issawiya remain despite their absence in the lofty de-Palestinized views from Efrat or Mount Scopus respectively, antagonistic landscapes like Efrat and HUJI on Mount Scopus are often compelled to encompass the object of their antagonism. And, in doing so, they inadvertently reproduce the narratives of the antagonized community that the new landscape was meant to eliminate.

In the end, by characterizing both a settlement that is considered illegal under international law and a university campus as antagonistic landscapes, the goal here is not to reveal something particular about these two very different places. Instead, the aspiration is to establish the wider applicability of the notion of "antagonistic landscapes," in Israel-Palestine and beyond.

\section{ON VERTICALITY}

A week after my stay in Efrat, a Palestinian friend drove me to Wadi an Nis to interview the villagers about their experience living adjacent to an Israeli settlement. However, as we entered the village it became quite evident that Wadi an Nis is located, not adjacent to Efrat but, quite literally, in its 
shadow. The Palestinian village may have been invisible in the "peaceful views" from Efrat. But the hilltop settlement towers over Wadi an Nis and is nearly inescapable in the views from the valley. We parked our car next to the Abu Bakr As Siddik mosque, the only mosque in the village, and approached two young men who were sitting on the steps outside a house. After exchanging pleasantries, my friend said, "we want to know more about your experience living next to the settlement." They fell silent. The word "settlement" (or mustawtana in Arabic) had clearly made them nervous and one of them replied hastily, "It's all fine. No problem."

At that point another man had arrived on the scene. He pulled us aside and said, "We have to be careful. They can see everything that is happening here from Efrat. They will cause problems if we say too much." 2 We decided to leave. But, as we made our way to the car, an elderly man sitting across the road from the house waved us over. He had overheard our conversation with the others and was willing to answer our questions. I asked him if he was concerned about being reprimanded by the Israeli authorities for talking to us. He smiled and said, "I'm too old to care." I then asked him, "What is the relationship between the people in Wadi an Nis and the settlement." He replied, "There is no relationship. They stand on top us. They try to control us like this. For them this is their land. We are just random people who live here temporarily." During my stay in Efrat, my host Ilan confirmed the existence of such a perception of Palestinians among settlers when he said, "I don't think about the Palestinians down there [in Wadi an Nis]. They want to live here, that's okay. But they have to remember, us Jews are the owners of this land."3 The elderly man from Wadi an Nis then continued, "They can think this is all their land. But we know that this is Palestinian land. This is mine. I was born on this land. I grew up on this land. I will die here."4

In a sense, the landscape that makes up (and surrounds) Efrat personifies what some scholars would term a prototypically contested landscape. It is often argued that the identity of a landscape is constructed. That is to say, this identity is not stable, or a given. Instead, it is dynamic, "unfixed" and formed "out of the particular set of social [and political] relations which interact at a particular location” (Massey, 1994: 168). For instance, in Yeoh and Kong's work on Singapore's Chinatown, this identity was formed out of the "negotiation of power" between the city's elite - namely, "planners, architects, administrators, politicians, property owners [and] developers" - and "everyday people" (Yeoh and Kong, 1994: 18). In Vietnam, Sikor writes, it was the encounter between centralized, state-mandated legal understanding of land ownership and a local community's "lived land relations" that lent itself to the identity of the country's rural landscape (Sikor, 2004: 75-95). 
And, in Fairhead and Leach's description, the identity of the Ziama reserve in Guinea is defined by the relations between conservationists who consider the area to be essential "for the preservation of habitats and biodiversity" and the local population who value the land on the basis of vastly different socioeconomic priorities (Fairhead and Leach, 1994: 482).

As may be apparent above, such social and political relations are, however, often conflict-ridden not least because they symbolize encounters between very different perceptions of the landscape. So, in places like Efrat and Wadi an Nis, where there are multiple, divergent narratives of to whom the land belongs (Kong and Law, 2002: 1504), the identity of the landscape is not just unfixed and dynamic; it is contested. Of course, the contested-ness of the landscape in Efrat and Wadi an Nis is an outgrowth of the spatial politics of Israel-Palestine in general where the "wider ethnonational tensions" (Yiftachel and Yacobi, 2003: 678) are often reflected in the conflict over land and territory (Gregory, 2004; Joronen, 2019; Shehadeh, 2008). But, does the term "contested" substantially represent the entirety of the spatial politics at play?

Efrat is contested in the sense that there are two distinct sets of narratives that ascribe two divergent identities to the landscape. But the term "contestation" - meaning a "process of disputing" (Stevensen 2010: 376) - and the expression "contested landscapes" also lead us to visualize a "horizontal" struggle, involving to two (or more) parties, facing each other, combating to materialize the dreams that animate their claims to the landscape. This horizontality does not necessarily ignore the existence of a power differential. Undoubtedly, the power differential was central in the contestation between elite and everyday "ways of seeing” the landscape in Singapore's Chinatown (Yeoh and Kong, 1994: 18). It was present in the way conservationists ignored the local population's "social and political relationship" with the Ziama reserve (Fairhead and Leach, 1994: 482-483) as well as in the manner the new land law of 1993 in Vietnam disregarded the rural population's "lived relations to the land" (Sikor, 2004: 76). And, it is the existent power differential in Israel-Palestine that allows the Israeli military to maintain what Jeff Halper calls a "matrix of control" that helps consolidate and facilitate the Israeli settler presence in the occupied West Bank and Jerusalem, at the expense of Palestinian communities (Halper, 2008: 141-174). To this end, Mitchell was right to argue that a discussion of power is inevitable in any deliberation of what a landscape is and does as it is often "an instrument of...power, perhaps even an agent of power" (Mitchell, 1994: 1). That said, irrespective of the nature of the power relations at play, the concept of "contested landscapes" serves primarily to indicate that the spatial identity of the place is a subject of a disagreement. The disagreeing parties in Singapore, 
Guinea, Vietnam and Israel-Palestine may have vastly unequal material resources at their disposal. However, the term "contested" only suggests the existence of overlapping (and conflicting) perceptions of the identity of a landscape.

But what Efrat is and does is about much more than just the existence of overlapping/conflicting claims to the landscape. It is about a certain verticality. And, to this effect, the concept of antagonistic landscapes differs from the notion of contested landscapes, in the sense that it highlights the existence of a power differential by politicizing the physicality of a place. The dream in Efrat is of a landscape that is devoid of Palestinian existence. With the entire settlement then built facing away from Wadi an Nis, the resultant "peaceful views" (of other nearby settlements) thus simulates a de-Palestinized landscape. This simulation would not have been possible if Wadi an Nis was in the line-of-sight of settlers in Efrat. It is only because Efrat is located on higher ground that, by virtue of its altitude, the Palestinians living in its vicinity naturally descend to the periphery of one's view and those looking out from the settlement are able to ignore the Palestinian presence. Further, as I have demonstrated earlier, this relegation of Wadi an Nis to the periphery gained some materiality as it gave the curious settler and my host in Efrat the pretence to claim Palestinian non-existence and deny the Palestinian claim to the landscape.

That Efrat's altitude allows its residents to feign Palestinian non-existence thus highlights the very privilege of inhabiting higher ground. This privilege is evident in Michel de Certeau's The Practice of Everyday Life and, as the author writes, in the "pleasure" of viewing the entirety of New York City from above. He notes that rising to the top of the World Trade Center lifts one "out of the city's grasp." And, being able to escape the "rumble" and "nervousness" of life in New York City in this way, made the urban landscape becomes comprehendible. Thus, de Creteau concludes, higher grounds "allows one to read it [i.e. the city], to be a solar Eye, looking down like a god" (de Creteau, 1984: 94). Similarly, Kenneth Olwig notes that higher ground lets us "overlook" the middle ground that lies below. That is to say, the "elevated position" empowers one to focus on the horizon and "the scenic space." This in turn "provides a powerfully transcendent and sublime experience of the world" unencumbered by the complexities of the middle ground (Olwig, 2018: 9).

In this sense, Wadi an Nis is the middle ground that complicates (and challenges) the settler presence and the elevated position of Efrat helps overlook this complexity. Though, I would argue that there is a certain specificity of the antagonistic landscape, not least by way of the antagonism of its altitude. 
The term "antagonistic" means active opposition or hostility towards something (Stevensen, 2010: 65). And, Efrat's active opposition and hostility towards Palestinians is visible in the way its altitude privileges a view that overlooks the undesirable presence (of Wadi an Nis) in the landscape. But this manner of overlooking the middle ground is not done simply in favour of a transcendent and sublime view of the world. Efrat purposefully overlooks Wadi an Nis in order to direct the gaze of those looking out on a much more "benign" presence - namely, the other settlements located in its vicinity. Further, the hope is that this way of overlooking Palestinians would eventually materialize in the actual de-Palestinization of the landscape. The extent to which this antagonistic landscape is able to realize the dream of Palestinian non-existence is a matter I will discuss later in this article. However, the distinguishing feature of the antagonistic landscape is that the urge to antagonize, not least by means of a privileged inhabitation of (and views from) higher ground, is its primary purpose.

\section{THE “VIEW” FROM MOUNT SCOPUS}

The HUJI campus on Mount Scopus was also shaped by a dream - albeit, a dream of reviving a nation. Founded in 1918, three decades before the establishment of the State of Israel, the university was a marque initiative of Zionist activists in Europe. It served a practical purpose as a place of refuge for Jewish academics and students "at a time when universities in Europe were setting quotas on the number of Jews admitted" (Dolev, 2016: xix). Additionally, the building of the university was also considered deeply synonymous with the re-making of the Jewish nationhood. It was almost as if HUJI was meant to symbolize Israel before the actual establishment of the State of Israel. And, just like the state was to mark the revival of the Jewish nation, so too was the academic institution meant to secure the dream of extending and renewing "the Jewish heritage [albeit] through modern scientific methods" (Dolev, 2016: xix).

This symbolism was written into the design of the campus. For instance, standing atop Mount Scopus, the university has unhindered views of Haram al Sharif or Temple Mount, the location of the Second Temple (or Herod's Temple). With HUJI (especially during its planning phase) often referred to as the Third Temple, the university then embodied the re-establishment of the severed connection between a historically persecuted and exiled people and their divinely ordained homeland (Dolev, 2016: xviii). Aesthetically, the buildings of the original campus were also inspired by Arab architecture as a way of ensuring that they blend with (and seem indigenous to) the surrounding landscape (Dolev and Gordon, 1992). However, as was pointed out to me by an Israeli architect during 
a tour of the HUJI campus in December 2015, the (Arab architecture-inspired) domes and arches are also "grand and khokhanoti [forceful/powerful] and are supposed to symbolize the muscularity of Zionism and the Jewish nation." ${ }^{5}$ It is therefore not surprising that the historian Hagit Lavsky should write, "The history of the Hebrew University of Jerusalem is...not only a chapter in the history of intellectual human endeavour but the story of the Jewish national awakening, a mirror of the emerging modern Jewish culture, and a pillar of the developing Israeli society” (Lavsky, 2015: 1).

Like Efrat, the manner in which HUJI communicates the "dream" of Jewish national awakening also antagonizes Palestinians. Historically, a sense of antagonism towards Palestinians was already inscribed in the foundations of the university. For instance, when the designers of the original master plan of HUJI ${ }^{6}$, Patrick Geddes and Frank Mears, incorporated the Arab style of architecture prevalent in Palestine, they did so with a sense of contempt for the Palestinian population. In a letter, Geddes wrote,

"... any Western eye can see that the Arabs are dirty, untidy, in many ways degenerate, and is all too likely to overlook, or have difficulty in seeing, the qualities of their buildings, even those of the fine houses of Damascus type in Jerusalem, with ample courtyards, airy rooms of ample proportions within, and so on" (Dolev, 1998: 223).

Geddes then insisted it was the responsibility of the Zionists and HUJI to fulfil the utmost potential of the Arab style of architecture by "crystallising anew its old and simple, useful and practical, economical and homely way and style of building" into a new campus atop Mount Scopus that would symbolize "New Jerusalem upon the hill” (Dolev, 1998: 224).

The contemporary campus is also dotted with nationalist iconography that seems to proclaim that the university caters primarily to the State of Israel and its proponents. For instance, a sign on a wall on campus dedicated by the American Friends of Hebrew University (AFHU) ${ }^{7}$ to members of its Hollywood/Hallandale Chapter declares HUJI to be the "university of the Jewish people." Another sign, dedicated to the victims of a bombing on campus ${ }^{8}$, similarly proclaims that the university will maintain its resolve and "continue its mission of research and teaching in an atmosphere of openness and tolerance for the benefit of Israel [and] the Jewish people." The campus also houses several archaeological artefacts that connect the university to Jewish history and aim to establish its status as an institution that contributes to the renewal of Jewish heritage. This includes a marble statue of a ruler from the Temple of Augustus in Samaria built by King Herod and a stone from the Third Wall of the Second Temple that adorns the façade of The Institute of Archaeology. 
Expectedly, Palestinian students feel alienated by the Israeli-ness of the campus and by what they consider an attempt to de-Palestinize a landscape that they consider integral to the Palestinian national territorial home. During our interview in 2015, a Palestinian alumnus of HUJI said to me,

For us, the campus, Mount Scopus and the surrounding area is Palestinian land. But when I was a student it was clear that the university wants to show that this campus is only for Israelis. Part of the problem are all the Israeli flags, signs and statues on campus. It is also not allowed to do any political action or demonstrations supporting Palestinians. But if there is a war on Gaza the university always says it supports the Israeli troops. We also can't celebrate Palestinian culture. They have cultural activities celebrating the French, Americans. But you cannot do anything here as Palestinians. We are just expected to accept that this university is not for Palestinians. ${ }^{9}$

During Operation Protective Edge in 2014, HUJI (along with other Israeli universities) chose to publicly support the war on Gaza. In a letter to "friends and alumni" the university announced that it was "joining the war effort to support its warrior students, in order to minimize the financial burden." HUJI allowed donors to earmark their financial contributions "for the 'Protective Edge' fund" and provided assistance to "warrior students" in the form of "discounts and sales for reservists, extra tutoring before tests, rebates on test preparation courses, free extensions of gym memberships, special access to the library... and a 50 percent discount on monthly public transit passes" (Abunimah, 2014). However, in response to a silent demonstration by Palestinian students on campus in 2014 against the administrative detention of Palestinian prisoners held in custody indefinitely without trial, the university administration summoned campus security and the police (Jawabreh, 2015). Reflecting on the university's actions against the demonstrators, a Palestinian organizer of the protest said to me,

If you think about it, the behaviour of campus security matches the fact that this place is very alienating for Palestinians. Even though [being a Palestinian citizen of Israel] I speak Hebrew this place is made to be unfamiliar to us. You have to be socially, politically and culturally alienated in this place...Being a Palestinian and being a Palestinian woman, if you are in a lecture and you want to say something, and you say it powerfully, Israelis look at you in a strange way...Just being the only Palestinian in a classroom of fifty students is enough to alienate you. Just being a minority here is alienating. So, it's not easy being a Palestinian in Israeli academia in general and Hebrew University in particular. ${ }^{10}$

Considering the historical circumstances and purpose (of reviving the Jewish nation) that animated the establishment of HUJI on Mount Scopus, it is not surprising that the university displays a spatial identity that pays no deference to the Palestinian claim to the landscape. However, like in Efrat, its antagonism is also evident in its physical features, as its location on higher ground vis-à-vis 
Palestinian communities allows those looking out from the campus on Mount Scopus to overlook the Palestinian presence in the area.

To be sure, the HUJI campus on Mount Scopus is surrounded by several Palestinian villages. But one such neighbouring village Issawiya, located in the valley on eastern edge of the university campus, has come to symbolize the disparity that exists between Israeli and Palestinian spaces. Unmistakably, the well-maintained and carefully curated aesthetics of the campus stand in stark contrast to Issawiya's congested and garbage-filled alleyways that are neglected by the Jerusalem municipality. For more than a decade, vehicles from Issawiya have also been unable to drive out of the village in the direction of Mount Scopus because of an army checkpoint. Further, Palestinians students and the university's contracted workers from Issawiya are often searched by the police at the checkpoint before they are allowed to enter the campus. ${ }^{11}$ Describing this relationship between Issawiya and HUJI, the Israeli Journalist Nir Hasson is therefore right to argue that the campus is another "Israeli space constricting" the lives of Palestinians in the village (Hasson, 2016).

For my interlocutors from Issawiya, however, much of what the campus does to the neighbouring Palestinian communities is personified in the manner in which the village, quite literally, lives in its shadow. In May 2016 a Palestinian student Sara, a resident of the village, gave me a tour of Issawiya. We were walking along the edge of the village and the fence of the university when she said, "Issawiya is my home." Then she stopped abruptly to look up in the direction of the campus, that seemed to be spilling over the edge of the hill, and continued, "But if you look at the campus it stands above us. From Issawiya we have to look up to the campus on Mount Scopus. This means we look up, but they look down on us. This is the historic relationship we have with Hebrew University. It's a relationship between the colonizer and us. The goal is to make us disappear."12

Similarly, during an interview on campus, another Palestinian student from Issawiya Mariam said, "We know what the university does to nearby Palestinian communities. Issawiya is on the edge of campus. But we are not equal. Yes, I am lucky to be studying here but we are treated mostly as inferior to the Israeli students." Then, referring to the many Palestinian contracted workers employed by the university and she added, "Most people from my village work here as cleaners, they serve the food on campus, they do all the dirty work. So, of course they live on top of the hill and we are at the bottom. This difference in height maybe creates the thinking that they are better than. Also, if you stand on top of the hill and look down the Palestinians at the bottom seem small, they become invisible." 13 
HUJI undoubtedly towers over Issawiya in a multitude of ways. But, being located on a hill, it is its physical dominance over Issawiya that most significantly symbolizes the antagonism of the campus towards the Palestinians in its vicinity. Not unlike in Efrat, being on higher ground privileges the campus with a "peaceful view" of the landscape in which Palestinians descended to the physical (and metaphorical) periphery. And, nowhere was this more evident than in the views from the Jack, Joseph and Morton Mandel School for Advance Studies in the Humanities, located only a few meters from the campus fence that separates HUJI from Issawiya. When I walked through its main entrance in December 2015, Issawiya dominated the view from the floor-to-ceiling windows at the Mandel School. Yet, when I sat down in the lounge located on the floor below the entrance, the Palestinian village descended to the periphery of my view and Issawiya became the middle ground that I could choose to overlook. It was almost as if the view from the Mandel School was purposefully curated to simulate Palestinian absence.

Surprised by how easily Issawiya disappeared from landscape, I asked an Israeli student, who was sitting in the lounge at the time of my visit, about the view from the Mandel School. She said, "I consider myself a left-wing person and when I look down, I see the Palestinians and what the occupation does to people in Issawiya. There is no steady water supply. There are piles of trash. But if you sit here and look out you can easily ignore Issawiya." I then asked her, "Do you think this place was built like this on purpose so that Palestinians would disappear when we look out from here?". She replied, "In a way. Sitting up here you can pretend that Palestinians don't exist. When the donors came to inaugurate this building, they told us to sit here and enjoy the views of the Judean desert and did not mention the Palestinians." 14 That this view - one that allows one to overlook the Palestinian village in favour of the far more benign Judean desert on the horizon - serves its purpose was apparent during an interview with another Israeli student who was smoking on the balcony of the Mandel School. When I asked him about Issawiya and its relationship with the campus, he said, "That's an Arab neighbourhood. It's a problem area. We don't have too much to do with them." He then smiled and added, "But the good thing is at night you can't see it. The view of the desert in the dark is quite nice." 15

\section{THE NARRRATIVES OF THE ANTAGONIZED}

To ascribe a certain antagonism to the landscape in Efrat and the HUJI campus on Mount Scopus due to their altitude, may seem like the attribution of politics into what is, in essence, a natural landscape. 
After all, the altitudinal dominance of Efrat and Mount Scopus over Wadi an Nis and Issawiya respectively is a consequence of their natural, and not built, characteristics. But, W.J.T. Mitchell, in his nine "theses on landscape," reminds us that "Like money, landscape is a social hieroglyph that conceals the actual basis of its value. It does so by naturalizing its conventions and conventionalizing its nature" (Mitchell, 1994: 5). So, there is nothing natural about natural landscapes. For example, the declared goal of the Virgin Islands National Park on St. John, established "under the auspices of the United States Park Service," was to preserve a "natural" landscape (Olwig, 1980: 22). However, there was very little that was natural about this landscape because what existed before its establishment was a cultural landscape that "did not fit the American perception of a national park." And when this cultural landscape was erased, it was replaced by a landscape, "created" by an American governmental agency, that was far more in keeping with "foreign perceptions [i.e. American] of what constitutes a "natural' landscape" rather local perceptions of the same (Olwig, 1980: 29). Of course, the first American national park, Yellowstone, was not natural either. It was established on "the traditional buffalo hunting grounds of various" Native American communities. Approximately "4 million buffaloes were killed" and the indigenous population was "refused permission to remain in the area" in order to make way for the Yellowstone National Park and keep up the illusion of its "natural beauty" (Olwig and Olwig, 1979: 2). For this reason, Kenneth Olwig terms the notion of a "natural landscape" a "sleight of hand" that masks the deeply "constructed" nature of the identity that the presumed natural landscape embodies and communicates (Olwig, 2008: 74). Don Mitchell similarly argues that a landscape is hardly an "unwitting biography," as was once argued by Peirce K. Lewis (1979) in his "Axioms for Reading the Landscape: Some Guides to the American Scene." It is instead "produced," "actively made," "an act of will" and results from a "physical intervention into the world" (Mitchell, 2008: 34).

There is nothing natural about Efrat and Mount Scopus's altitudinal dominance either. In fact, the very act of establishing the settlement and the university campus on higher ground ensured that their altitude became an act of will representing a conscious physical intervention, steeped in the broader politics of Israel-Palestine. In the "story" of antagonistic landscapes I relay in this article, I am however less focused on the extent to which such landscapes are acts of will. Instead, I am more concerned with who has the privilege or power to make a physical intervention in the world. To this end, my conception of how an antagonistic landscape functions confirms Don Mitchell's assertion that a landscape "is an expression of power" and "determines what can and cannot be done" (Mitchell, 2008: 43). Efrat and Mount Scopus are also expressions of power, as is exemplified by their de- 
Palestinized views of the landscape. Moreover, in the way they materially and figuratively tower over Wadi an Nis and Issawiya, and allow those looking out from higher ground to simply overlook the Palestinian communities, such landscapes also seem to set the parameters for what Palestinians can and cannot do. Such expressions of power then expectedly antagonize Palestinians.

Except, does the feeling of antagonism constitute the entirety of their spatial experience of the antagonistic landscape? Is there no respite for the antagonized? Shelley Egoz argues that a landscape "is an existential component of humans and [therefore] is something that cannot be taken away from them" (Egoz, 2010: 26). At the outset, my Palestinian interlocuters seemed to acknowledge that the landscape they called their own had been taken away from them, at least materially. The elderly villager in Wadi an Nis claimed that the settlers in Efrat controlled the lives of Palestinians in the valley. The Palestinian students at HUJI said they felt alienated by the Israeli-ness of the university campus. Sara also revealed that she could not escape the campus' domineering presence in the view from her home in Issawiya. Nonetheless, they also insisted that the landscape remained an existential facet of their being as Palestinians. The villager in Wadi an Nis, for instance, noted that while the settlers would claim that the landscape of (and around) Efrat is theirs, the land is in fact Palestinian. He then insisted that he would die on the land of his birth and upbringing. In the same way, Sara said,

It is of course not easy to be from Issawiya and to be a student here. They have taken our land and the university is built on stolen Palestinian land. But they can say whatever they want. I know and all Palestinians know this is Palestine. They can put up flags, have checkpoints that make our lives more difficult. But whether I am in Issawiya or up on Mount Scopus I don't deal with the Israel symbols. I ignore them and say to myself that they have to have all these flags and nationalist symbols, make an Israeli show, because they are also aware that this is Palestinian land. They know that they have stolen this land and now have to convince everyone this is Israeli. Thinking like this makes me calm, normalizes things and I can survive this place as a Palestinian. ${ }^{16}$

Finally, seeing the trials of being a Palestinian student at HUJI on Mount Scopus, I asked Mariam, "Why did you decide to study at Hebrew University?". She replied, "It was my father's decision. He said that I should join the university. Why not? This is our [Palestinian] land after all. I still hold on to my language and heritage. That is how I fight and how this land remains ours." Mariam then paused and continued,

That does not mean that I don't have problems on campus. I am sorry to say this but you as a foreigner will never understand what we go through in class with Israelis. I am very vocal but it's frustrating to fight all the time. This university is designed to keep us down. But there are places on campus where I can go, and I know that there will definitely be some Palestinians. I can just sit there, talk to them and they will understand. ${ }^{17}$ 
In a sense, my Palestinian interlocutors displayed what could be termed as an urge to create, within the boundaries of a life of distress, an "unoccupied space"; namely, a realm of "heroic normality" (Hage, 2015: 165-168) that is not entirely inundated by the realities of life in the shadow of the antagonistic landscapes. Ghassan Hage saw this "heroic normality" in the household of a Palestinian martyr. The martyr's widow, for example, "reads the children some relatively apolitical children's books and tucks them in, wishing them goodnight with a warm kiss." In doing so, she provides her children with a subjectivity that is not solely informed by colonialism, the resistance to colonialism or their father's martyrdom in service of the Palestinian struggle against colonial rule. Conjuring such a space is heroic because it instils a semblance of normalcy in an utterly abnormal environment (Hage, 2015: 168). Laleh Khalili also wrote of young Palestinian women promenading on the Beirut seaside who, in doing so, created a similar space of normality outside the Palestinian refugee camps. While the occupation and resistance are what often defines the lives of these women, the pleasure of walking along the seaside creates "a sphere distinct and discrete from the domain of resistance" i.e. a sphere of normalcy that is not informed by the trials of being Palestinian (Khalili, 2016: 590-591). Evidently, my Palestinian interlocutors were also occupied, monitored and alienated. But, by finding a place on campus where they could be Palestinian, by insisting that the land was Palestinian despite the dePalestinized views of the landscape from Efrat, by attempting to ignore the presence of Israeli nationalist iconography on Mount Scopus or by simply asserting that one would live and die on the land of one's birth, they also strived to etch out a space for heroic normality that was not overwhelmed by the antagonism of the antagonistic landscape.

It may of course be instinctive for those living in the shadow of antagonistic landscapes to try and conjure an unoccupied space of normality. But there is also a fundamental fallacy in the manner in which an antagonistic landscape communicates, and strives to materialize, a dream - a fallacy that in turn allows the antagonized to prevail. Landscapes in general are the product of dreams. Brasilia, for instance, was designed and built as the modern national capital of Brazil in order to fulfil the dream of civilizing the indigenous population of the Central Plateau, which would then allow the political elite to establish its sovereignty over the territorial interiors (Holston, 1989: 17). Dholera, a proposed "smart city" in the western state of Gujarat in India, was conceived out of the postcolonial dream of modernization and development. It mirrors other "master-planned" Indian cities like Chandigarh, Bhubaneshwar, Cuttack, and Gandhinagar, and shared the dream of breaking with India's colonial legacy while embodying postcolonial India's “attempt to fashion a new society and economy” (Datta, 2015: 7). Finally, be it the imposition of Turkish nationalist iconography into the urban landscape of 
Kurdish majority Turkish cities or the words of Kemal Atatürk, "Ne mutlu Türküm diyene [How happy is the one who says I am Turkish], carved onto the hills of Turkish Kurdistan by the Turkish military - they are driven by the nationalist dream of a state where (Kurdish) citizens identify themselves as Turks and not as Kurds (Houston, 2005; Ozsoy, 2013).

So, it is not unusual that the landscape in (and around) Efrat and Mount Scopus are also animated by dreams. Their antagonism, however, comes to the fore in the manner in which these dreams are premised on Palestinian absence. Further, they aim to materialize this dream (of Palestinian absence) through their verticality that eliminates Palestinians from the views of the landscape. The problem, however, is that since Efrat and HUJI on Mount Scopus are animated by utopian dreams, they are frequently unable to entirely eliminate what already exists and instead make use of what they aim to replace. This fallacy was present, for example, in the making of Brasilia. The patrons of a Brazilianized Brasilia designed the new capital city in a way that symbolized the Central Plateau's break from Brazil's indigenous past. However, the process of making the new Brasilia and civilizing the people of the Central Plateau faced a paradox as the "planning instruments" had to utilize what already existed. This not only reproduced the Central Plateau's indigeneity that the new modern capital city hoped to eliminate, but also effaced the premise that necessitated the making of a new Brasilia - one that centred on differentiating between the "civilized" utopia and the "uncivilized" that it aimed to replace. It was this inherent paradox that then allowed those antagonized by the dream (and constituent landscape) of the new Brasilia to reassert the sociocultural norms and values that the patrons of the new national capital considered undesirable (Holston, 1989: 289-290).

Dholera in Gujarat also makes use of all that it aims to replace because it is a place that already exists. What exists may not abide by the vision of a new India. But an "unmodern," "undeveloped" village with the same name exists in the vicinity of the proposed smart city. It, along with twenty-one other villages, are then meant to constitute the new Dholera (Datta, 2015: 11). This means that while the smart city premises itself as a utopian construct synonymous with the modern, developed, and postcolonial India, it is hardly "planned on terra nullius" (Jazeel, 2015: 28). It instead makes use of what exists - not least, in terms of the land that has been forcefully taken from farmers (Bennett, 2016). The new Dholera has yet to come to fruition. But it is likely that the smart city will share the destiny of other planned cities in India and only reproduce the urban maladies of the country's past that it was meant to replace. 
This problematique was also evident at the HUJI campus and in Efrat. On Mount Scopus, one could argue, the presence of Palestinian contracted workers and an ever-growing Palestinian study body are all reminders that HUJI also makes use of what it aims to replace. Yet, the insistent manner in which the campus, from higher ground, attempts to curate views of the landscape in which Palestinians are absent also reveals a certain insecurity. The Mount Scopus campus may display an Israeli-ness. But, be it the donors who insisted that one must enjoy the views of the Judean desert from the Mandel School, the floor-to-ceiling windows at the school that ensure that Issawiya is in the periphery of one's view or the Israeli student who said that in the dark the Palestinian village disappears from the view from the Mandel School - they all exhibit an anxiety about being able to see Palestinians. As if, it is feared, being able to see Palestinians would undermine the very premise of the dream that the campus is meant to communicate and materialize. Further, this also reveals that on Mount Scopus there was a certain awareness that what was meant to be eliminated persists and, while views from higher ground allow one to feign their absence, Palestinians remained a constituent element of the new landscape. In Efrat, the settler revealed that the views from the settlement feigned peace. To this end, Efrat is designed and planned in a way that ensures that all its structures look away from the Palestinian community in its vicinity. This de-Palestinizes the view of the landscape. But, like on Mount Scopus, the insistent manner in which the settlement looks away also displays both an anxiety that being able to see Palestinians would undermine the illusion of peace as well as an awareness that while Palestinian presence was supposed to be erased, they remained an integral facet of the landscape. After all, the settler in Efrat displayed this awareness when she said, 'This place is not peaceful. We have Arabs here. But you can't see them from here. We like to maintain peaceful views."

In the end, as I have argued earlier, the antagonized (and occupied) may instinctively strive to conjure an unoccupied space while living in the shadows of the antagonistic landscapes. However, such landscapes' above-described inability to materialize utopian dreams ensures that the stories they communicate reflect not just the narratives authored by those who have the power and resources to make a physical intervention in the world. They also communicate the stories of the antagonized. This may be unintended. After all, by looking away from Wadi an Nis or by creating a view in which Issawiya to the periphery, these landscapes are in fact trying not to communicate the narratives of the antagonized. However, their inherent inability to efface the neighbouring Palestinian communities ensures that antagonistic landscapes (albeit, inadvertently) relay the narratives of both the antagonistic and the antagonized. 


\section{CONCLUSION}

While writing about the Pueblo Indian communities, John Brinckerhoff Jackson suggests that the vernacular landscapes these communities call their own can be difficult to view, seeing as the "symbols of [European] permanent power" have consolidated their presence over them. Yet, in the shadow of these symbols of power remain "thousands of small and impoverished vernacular landscapes, organizing and using spaces in their traditional way and living in communities governed by custom, held together by personal relationships." In this sense, Jackson concludes, a landscape tells a multi-dimensional story that includes the narratives, not just of those who own it, but also of those seemingly eclipsed by the symbols of political power that have been installed by the new owners (Jackson, 1984:150).

Such a line of inquiry is equally pertinent to an antagonistic landscape. In this article I have characterized the landscapes of (and around) Efrat and HUJI on Mount Scopus as prototypical examples of antagonistic landscapes. For one, being placed on higher ground, allows them to feign the absence of Palestinians in the landscape - a landscape that, for Palestinians, is integral to the aspired-for Palestinian national territorial homeland. This attempt to efface them from the land naturally antagonizes Palestinians who live in the shadows of the antagonistic landscapes. But, the absence of Palestinians is, after all, a utopian dream. And, my Palestinian interlocutors insisted that the landscape, while materially taken away, remains an integral facet of their existential being as Palestinians. As a consequence, being unable to efface the antagonized ensures that an antagonistic landscape communicates not just the narrative (and dreams) of those that antagonize. It also relays the narratives of the antagonized.

There is of course a particularity of the politics of Israel-Palestine that lead Efrat and Mount Scopus to be antagonistic in the manner that I have described in this article. Specifically, the settler colonial ideological basis of the establishment of the State of Israel, that is premised on the erasure of the indigenous, encourages a spatial politics that aims to materialize the settler's dream of the indigene's non-existent. So, as an outcome of this ideology, it is not surprising that the altitudinal dominance of Mount Scopus and Efrat over Palestinian communities in the vicinity is a common feature of most Israeli settlements in the occupied West Bank. But, by characterizing antagonistic landscapes in this 
article in view their physicality, rather than the underlying political ideology, also allows for the concept to be applicable across political contexts. Just as Israeli settlements antagonize Palestinian communities in their vicinity on the basis of their altitude, a similar "story" of antagonistic landscapes could be relayed through say the landscapes of Kurdish-majority Turkish cities where, as I have mentioned earlier, the Turkish state has imposed nationalist iconography that claim the non-existence of Kurdish nationhood. With the iconography often placed higher ground (high buildings and hills), the concept of "antagonistic landscapes" can then be instructive in better understanding both how such landscapes' verticality antagonizes Turkey's Kurdish population and the way the antagonized contend with antagonistic message of the landscape that towers over them.

Antagonistic landscapes, as a conceptual framework, can also be applicable to urban renewal initiatives in India. The proliferation of high-rises and overpasses serve an upwardly mobile urban economic class. But what is the effect of inhabiting higher ground? What kind of view of the landscape does altitude privilege and allow one to overlook? And, how does the altitudinal dominance of this landscape effect (and antagonize) the urban poor who are often excluded from inhabiting higher ground? Of course, by arguing for the wide applicability of the concept my intention here is not undermine the particular historical, political and socioeconomic contexts that shape such landscapes. However, its applicability across contexts does nonetheless reveal the manner in which the physicality of landscapes can be animated and consequently politicized by dreams. The landscape may be tasked to communicate and materialize the dream of development, the dream of modernization, the dream of a homogeneous nation, or simply the dream of an unimpeded claim to a divinely ordained homeland. But, irrespective of the particular nature of a dream, the concept "antagonistic landscapes" provides a scope for exploring its violence as it acknowledges that what may be a dream for some can also antagonize others.

\section{REFERENCES}

Abunimah A (2014) "Warrior students": how Israeli universities are supporting war crimes in Gaza. The Electronic Intifada. 18 August. https:/electronicintifada.net/blogs/ali-abunimah/warriorstudents-how-israeli-universities-are-supporting-war-crimes-gaza (last accessed 9 July 2019)

Alsaafin, L (2017) Palestine 2015 attacks triggered new path of resistance. Al Jazeera. 4 October. https://www.aljazeera.com/indepth/features/2017/10/years-palestine-2015-resistance-continues$171001142310665 . h t m l$ (last accessed 8 July 2019) 
Bardenstein C (1998) Threads of memory and discourses of rootedness: of trees, oranges and the prickly-pear cactus in Israel/Palestine. Edebiyat 8(1): 1-36

Bennett J (2016) Indian Government accused of grabbing land from farmers to build 100 smart cities. $A B C$ News. 25 October. http://www.abc.net.au/news/2016-10-25/indian-government-accused-ofgrabbing-land-from-farmers/7955390 (last accessed 8 July 2019)

Collins J (2012) Global Palestine. New York: Columbia University Press.

Datta A (2015) New urban utopias of postcolonial India: 'entrepreneurial urbanization' in Dholera smart city, Gujarat. Dialogues in Human Geography 5(1): 3-22.

de Certeau M (1984) The Practice of Everyday Life. Berkeley: University of California Press.

Dolev D (1998) Architectural orientalism in the Hebrew University - the Patrick Geddes and Frank Mears master-plan. Assaph: Studies in Art History Section B(3): 217-234.

Dolev D (2016) Facing the Temple Mount. The Planning and Building of the Hebrew University, 1919-1948. New York: Lexington Books.

Dolev D and Gordon H (1992) Architectural orientalism in early Zionist buildings: the case of Hebrew University. The Centennial Review 36(2): 361-372.

Egoz S (2010) The European Landscape Convention: A close view from a distance. In Proceedings of the Council of Europe, $8^{\text {th }}$ International Workshop for the implementation of the European Landscape Convention, European Spatial Planning and Landscape (pp 25-31). Strasbourg: Council of Europe Publishing.

Falah G (1999) The transformation and de-signification of Palestine's cultural landscape. In AbuLughod I, Heacock R and Nashef K (eds) The Landscape of Palestine: Equivocal Poetry (pp 97-106). Birzeit: Birzeit University Publications.

Fairhead J and Leach M (1994) Contested forests: modern conservation and historical land use in Guinea's Ziama Reserve. African Affairs 93(373): 481-512.

Gregory D (2004) Palestine under siege. Antipode 36(4): 601-606.

Griffiths M (2017) Hope in Hebron: the political affects of activism in a strangled city. Antipode 49(3): 617-635.

Hage G (2015) Alter-Politics. Critical Anthropology and the Radical Imagination. Victoria: Melbourne University Press.

Halper J (2008) An Israeli in Palestine. Resisting Dispossession, Redeeming Israel. London: Pluto Press. 
Hasson N (2016) The murky relations between the Hebrew University and its neighboring Palestinian village. Haaretz. 12 April. https://www.haaretz.com/israel-news/.premium.MAGAZINE-the-viewfrom-the-other-side-of-mount-scopus-1.5428825 (last accessed 8 July 2019)

Holston J (1989) The Modernist City. An Anthropological Critique of Brasilia. Chicago: University of Chicago Press.

Houston C (2005) Provocations of the built environment: animating cities in Turkey as Kemalist. Political Geography 24(1): 101-119.

Jackson J B (1984) Discovering the Vernacular Landscape. New Haven: Yale University Press.

Jazeel T (2015) Utopian urbanism and representational city-ness: on the Dholera before Dholera smart city. Dialogues in Human Geography 5(1): 27-30.

Jawabreh A (2015) Arab students in Israel say their voices are muffled. Al-Fanar Media. 7 August. https://www.al-fanarmedia.org/2015/08/arab-students-in-israel-say-their-voices-are-muffled// (last accessed 8 July 2019)

Joronen M (2019) Negotiating colonial violence: spaces of precarisation in Palestine. Antipode 51(3): 838-857.

Khalili L (2016) The politics of pleasure: promenading on the corniche and beachgoing. Environment and Planning D: Society and Space 34(4): 583-600.

Kong L and Law L (2002) Introduction: contested landscapes, Asian cities. Urban Studies 39(9): 1503-1512.

Lavsky H (2015) Introduction. In Selzer A (ed) The History of the Hebrew University of Jerusalem. Who's Who Prior to Statehood: Founders, Designers, Pioneers (pp 1-14). Jerusalem: The Hebrew University Magnus Press.

Lewis P F (1979) Axioms for reading the landscape: some guides to the American scene. In Meinig D (ed). The Interpretation of Ordinary Landscape: Geographical Essays (pp 11-32). New York: Oxford University Press.

Massey D (1994) Space, Place and Gender. Cambridge: Polity Press.

Mitchell D (2008) New axioms for reading the landscape: paying attention to political economy and social justice. In Coscoat Jr. J L W and Johnston D M (eds). Political Economies of Landscape Change: Places of Integrative Power. Dordrecht: Springer.

Mitchell W J T (1994) Imperial landscapes. In Mitchell W J T (ed) Landscape and Power (pp 5-34). Chicago: University of Chicago Press.

Olwig K F (1980) National parks, tourism, and local development: a West Indian case. Human Organization 39(1): 22-31. 
Olwig K F and Olwig K R (1979) Underdevelopment and the development of "natural" park ideology. Antipode 11(2): 16-26.

Olwig K R (2008) 'Natural' landscapes in the representation of national identity. In Graham B and Howard P (eds). The Ashgate Research Companion to Heritage and Identity (pp 73-88). Hampshire: Ashgate Publishing.

Olwig K R (2018) Transcendent space, reactionary-modernism and the "diabolic" sublime: Walter Christaller, Edgar Kant, and geography's origins as a modern spatial science. GeoHumanities 4(1): $1-26$.

Ozsoy H (2013) The Missing Grave of Sheikh Said: Kurdish Formations of Memory, Place and Sovereignty in Turkey. In Visweswaran K (ed). Everyday Occupations: Experiencing Militarism in South Asia and the Middle East (pp 191-220). Philadelphia: University of Pennsylvania Press.

Salamanca O J, Qato M, Rabie K and Samour S (2012) Past is present: settler colonialism in Palestine. Settler Colonial Studies 2(1): 1-8.

Sen, S (2020) Decolonizing Palestine: Hamas between the Anticolonial and the Postcolonial. Ithaca: Cornell University Press.

Shehadeh R (2008) Palestinian Walks: Notes on Vanishing Landscape. London: Profile Books.

Sikor T (2004) Conflicting concepts: contested land relations in North-western Vietnam. Conservation \& Society 2(1): 75-95.

Stevensen A (2010) Oxford Dictionary of English. Oxford: Oxford University Press.

Tuastad D (2017) The violent rise of Palestine's lost generation. Middle East Critique 27(2): 159169.

Twersky M I (2012) Ten Years Later, Mothers of Hebrew U. Bombing Victims Look Back. Haaretz. 27 July. https://www.haaretz.com/looking-back-at-hebrew-u-slaughter-1.5271834 (last accessed 8 July 2019)

Yeoh B S A and Kong L (1994) Reading landscape meanings: state constructions and lived experiences in Singapore's Chinatown. Habitat International 18(4): 17-35.

Yiftachel O and Yacobi H (2003) Urban ethnocracy: ethnicization and the production of space in an Israeli 'mixed city.' Environment and Planning D: Society and Space 21(6): 673-693.

\footnotetext{
${ }^{1}$ Field Notes, Efrat, November 2015.

${ }^{2}$ Field Notes, Wadi an Nis, November 2015.

${ }^{3}$ Author Interview, Efrat, November 2015.

${ }^{4}$ Author Interview, Wadi an Nis, November 2015.

${ }^{5}$ Author Interview, Jerusalem, December 2015.

${ }^{6}$ Only two buildings from this master plan were eventually constructed.
} 
${ }^{7}$ On its official website AFHU describes itself as a charitable organization that raises "awareness and funds for the university" (AFHU, 2018).

${ }^{8}$ On July $31^{\text {st }}, 2002$, Hamas claimed responsibility for a bomb that was placed in a bag in the Frank Sinatra Cafeteria on Mount Scopus. The subsequent explosion killed 9 people and injured 85 (Twersky, 2012).

${ }^{9}$ Author Interview, Jerusalem, December 2015.

${ }^{10}$ Author Interview, Jerusalem, June 2016.

${ }^{11}$ Field Notes, Jerusalem, May 2016.

${ }^{12}$ Author Interview, Issawiya, May 2016.

${ }^{13}$ Author Interview, Jerusalem, December 2015.

${ }^{14}$ Author Interview, Jerusalem, December 2015.

${ }^{15}$ Author Interview, Jerusalem, December 2015.

${ }^{16}$ Author Interview, Issawiya, May 2016.

${ }^{17}$ Author Interview, Jerusalem, December 2015. 